\title{
UNDERSTANDING URBAN REGENERATION IN TURKEY
}

\author{
E. Candas ${ }^{\text {a* }}$, J. Flacke ${ }^{\text {b }}$, T. Yomralioglu ${ }^{\text {a }}$ \\ a Istanbul Technical University, Civil Engineering Faculty, 34469 Maslak Istanbul, Turkey - (ecandas, tahsin)@itu.edu.tr \\ ${ }^{\mathrm{b}}$ University of Twente, Faculty of Geo-Information Science and Earth Observation, 7500 AE Enschede, Netherlands - \\ j.flacke@utwente.nl
}

SpS13-FIG

KEY WORDS: Informal Settlements, Urban Regeneration, Spatial Data Infrastructure, Disaster Risk

\begin{abstract}
:
In Turkey, rapid population growth, informal settlements, and buildings and infrastructures vulnerable to natural hazards are seen as the most important problems of cities. Particularly disaster risk cannot be disregarded, as large parts of various cities are facing risks from earthquakes, floods and landslides and have experienced loss of lives in the recent past. Urban regeneration is an important planning tool implemented by local and central governments in order to reduce to disaster risk and to design livable environments for the citizens. The Law on the Regeneration of Areas under Disaster Risk, commonly known as the Urban Regeneration Law, was enacted in 2012 (Law No.6306, May 2012). The regulation on Implementation of Law No. 6306 explains the fundamental steps of the urban regeneration process. The relevant institutions furnished with various authorities such as expropriation, confiscation and changing the type and place of your property which makes urban regeneration projects very important in terms of property rights. Therefore, urban regeneration projects have to be transparent, comprehensible and acceptable for all actors in the projects. In order to understand the urban regeneration process, the legislation and projects of different municipalities in Istanbul have been analyzed. While some steps of it are spatial data demanding, others relate to land values. In this paper an overview of the urban regeneration history and activities in Turkey is given. Fundamental steps of the urban regeneration process are defined, and particularly spatial-data demanding steps are identified.
\end{abstract}

\section{INTRODUCTION}

\subsection{Cities in Turkey}

Rapid urbanization has always been a striking management issue for the governments in developing countries. On average, today's developed countries increased their urban share of population by 7.7 percent between 1880 and 1900; today's developing countries have seen urban share increases of 8 percent between 1985 and 2005 (World Bank, 2008; World Bank, 2015). Similarly, Turkey experienced a rapid urbanization since the late ' 50 s and is still facing the effects of the period.

From the 50s with the decline of the agriculture and rise of the industry sector, migration from country to towns increased rapidly in Turkey. Cities which are not ready for such a rapid population growth, especially mega cities like Istanbul, Ankara and Izmir, faced housing problems that brought up slums and urban sprawl. Today, cities accommodate over 75 percent of the country's population and contribute substantially to its industrially-competitive economy (World Bank, 2015).

While urbanization was steadily increasing during 1950s-70s, it was during the 1980s that Turkey experienced a major surge of rural migrants to cities, causing rapid expansion of informal areas in urban settlements. Thereafter, a permissive tenure regime granted squatters on urban public land legal status that prompted both households and host municipalities to invest in their dwellings and neighborhood infrastructure (World Bank, 2015). This adoption of Turkey paved the way for other migrants and other illegal settlements.

\footnotetext{
* Corresponding author
}

Urban redevelopment activities started with demolishment of slums; after the rapid population growth urban land in need of new inhabitants tried to be reproduced by means of regeneration projects. In 80 s urban development became more important as a political tool and this directly impacted the legislative regulation, for example Development Law (1985) and Mass Housing Law (1984).

\subsection{Cities under Disaster Risk}

Earthquakes, in Turkey, are the most significant types of hazards, followed by floods and landslides that turn in to disasters (Güzey, 2016). Throughout the history Turkey faced major earthquakes, floods and other disasters. But the 1999 Marmara Earthquake clearly showed that buildings in cities were old and vulnerable against potential disasters. Despite the fact that lots of lessons were taken and promises were given by the politicians, only after a few years later, the 2011 Van Earthquake occurred. After the earthquake killed more than 600 people and damaged 11000 buildings, government took serious steps and the last legislative arrangements were then made.

In addition to a number of supplementary measures taken in earthquake regulations between 2007 and 2009, the Law on the Regeneration of Areas under Disaster Risk, No. 6306, which was brought into effect in 2012, has become the preliminary regulation in disaster prevention (Güzey, 2016).

\subsection{Need for a Rearrangement}

Disaster management policies in Turkey were perceived as lagging behind developed countries, institutional shortcomings, 
coordination problems and lack of legislation (Balamir, 2007). After the Van earthquake in 2011, the Government urgently started new legal and organizational arrangements. Announcement of the Law on the Regeneration of Areas under Disaster Risk is followed by the establishment of The General Directorate of Urban Transformation and Infrastructure, within the Ministry of Environment and Urbanization.

The term "Urban Regeneration (UR)" is introduced by many authors as producing economically, physically, socially and environmentally permanent solutions in areas that have lost their urban functionalities; implementing comprehensive sets of actions with a legal basis undertaken in order to regenerate lost or abandoned social relations (Thomas, 2003; Roberts, 2000; Polat and Davutoğlu, 2007; Usta, Ülger and Iban, 2015). When Turkish cities are taken into consideration, urban regeneration refers to an arrangement of property whose land has crooked and dilapidated constructions, sensitive to natural hazards and urban risks, with insufficient and poor infrastructure, dense, illegal and unsettled (Ülger, 2010).

When Turkish cities are taken into consideration, urban regeneration refers to an arrangement of property whose land has crooked and dilapidated constructions, sensitive to natural hazards and urban risks, with insufficient and poor infrastructure, dense, illegal and unsettled (Usta et. al., 2015).

The objective of this paper is to define fundamental steps of the urban regeneration process and spatial data related to these steps. For that purpose, the paper is designed in 4 chapters. In the introduction chapter the cities of Turkey, disaster risk of the cities and need for a new arrangement are explained. In the second chapter legal basis of the urban regeneration process is tried to be reviewed. Then in the third chapter the theory and the practice are described. The paper concludes how the urban regeneration process should be improved.

In this paper, the Law defines the Law on Transformation of Areas Under Disaster Risk No. 6306, the Regulation defines the Regulation on Implementation of Law No. 6306, the Ministry is the Ministry of Environment and Urbanization and the related institution refers to the Municipality.

\section{BACKGROUND}

\subsection{Legal Background}

There are various legislations dealing with different aspects of urban regeneration in Turkey (Table 1). In 1966, 775 numbered Slum ("Gecekondu" in Turkish) Law came into force. This law regulates the rehabilitation of existing slums and can be accepted as the first legal arrangement for urban regeneration. It is followed by the 2985 numbered and 1984 dated Mass Housing Law. The aim of this law is transformation of slum areas, protection and renewal of the historical pattern and local architecture, and promotion of safe housing in disaster areas, all in the context of urban regeneration. Purpose of the 5104 numbered North Ankara Entrance Urban Regeneration Project Law that is issued in 2004, is to improve physical condition and environment of the north Ankara entrance and surroundings (Airport Road and the surrounding area) and to increase the quality of living and provide healthier life standards.

With the Municipality Law numbered 5393 and dated 2005, municipalities are authorized to implement urban regeneration and renewal projects in order to form residential areas, industrial areas, commercial areas, technology parks, public service areas, recreation areas and create all kinds of social reinforcement areas, reconstruct and restore the old parts of the city, protect the historical and cultural parts of the city and take precaution against disaster risk. 2005 dated and 5366 numbered Law on the Protection of Deteriorated Historical and Cultural Heritage through Renewal and Re-use aims reconstruction and restoration of protected areas and their surroundings in the concept of development of the areas and to form residential, commercial, cultural, touristic and social reinforcement areas, to take precaution against disaster risk, to renew and protect the historical and cultural heritages and to use them in order to make them live.

\begin{tabular}{lcll}
\hline Date & Number & Name of Law & Authority \\
\hline 1966 & 775 & Gecekondu Law & Municipality, TOKI \\
1984 & 2985 & Mass Housing Law & TOKI \\
2004 & 5104 & $\begin{array}{l}\text { North Ankara Entrance } \\
\text { Urban Regeneration Project } \\
\text { Law }\end{array}$ & $\begin{array}{l}\text { Ankara } \\
\text { Metropolitan } \\
\text { Municipality }\end{array}$ \\
2005 & 5393 & $\begin{array}{l}\text { Municipality Law } \\
\text { Municipality, }\end{array}$ & $\begin{array}{l}\text { Metropolitan } \\
\text { Municipality }\end{array}$ \\
& 5366 & $\begin{array}{l}\text { The Law on the Protection } \\
\text { of Deteriorated Historic and } \\
\text { Cultural Heritage through } \\
\text { Renewal and Re-use }\end{array}$ & $\begin{array}{l}\text { Municipality, } \\
\text { Ministry of } \\
\text { Urbanization and } \\
\text { Cultural Heritage } \\
\text { Preservation Board }\end{array}$ \\
\hline 2012 & 6306 & $\begin{array}{l}\text { The Law of Transformation } \\
\text { of Areas under the Disaster } \\
\text { Risks }\end{array}$ & $\begin{array}{l}\text { Ministry of } \\
\text { Urbanization }\end{array}$ \\
\hline
\end{tabular}

Table 1. Legislative background of UR in Turkey

\subsection{The Urban Regeneration Law}

All these legislations are inadequate and they are not dealing the problem from the holistic view so they cannot offer a sustainable solution to urbanization problems. With the lessons taken from the past natural disasters and their devastating results, in 2012 the Law (numbered 6306) has enacted. The purpose of this law is to define the procedures and principles on rehabilitation, clearance and renewal of risky areas and risky buildings in order to constitute healthy and safe housing and environment, which are convenient in terms of the technical and artistic norms and standards.

\section{URBAN REGENERATION IN TURKEY}

The latest dated legislation on urban regeneration is No. 6306"The Law on the Regeneration of Areas under Disaster Risk", or commonly known as the Urban Regeneration Law. The purpose of this law to define the procedures and principles on rehabilitation, clearance and renewal of risky areas and risky buildings in order to constitute healthy and safe housing and environment which are convenient in terms of the technical and artistic norms and standards.

The Law does affect construction and real estate sectors deeply. The Ministry of Environment and Urbanization expects approximately 6-7 million dwellings nationwide (approximately $40 \%$ of total housing supply in Turkey) to fall as part of the urban regeneration law. The total cost needed for this regeneration project is estimated at 500 billion dollars by the government.

The aforementioned law aims to set forth principles and procedures regarding improvement, evacuation and renewal of areas under disaster risk and of lands and plots with structures 
under risks. Article 2 of the Law defines risky areas and risky structures, the deriving point of the law, according to which "risk areas" could engender loss of lives and property, due to surface structures or settlements, as identified by the Ministry or administration with the opinions of Disaster and Emergency Management Office, and as agreed on by the Council of Ministers upon the proposal of the Ministry (Tarakçı and Özkan, 2015).

\subsection{The Urban Regeneration Law in Theory}

In order to understand the basic steps of the UR process the Law No. 6306 and the related legislation are examined in detail. According to the Law and the Regulation basic steps of the UR process are listed as follow (Table 2). These steps define how UR should be done in respect to the legislation.

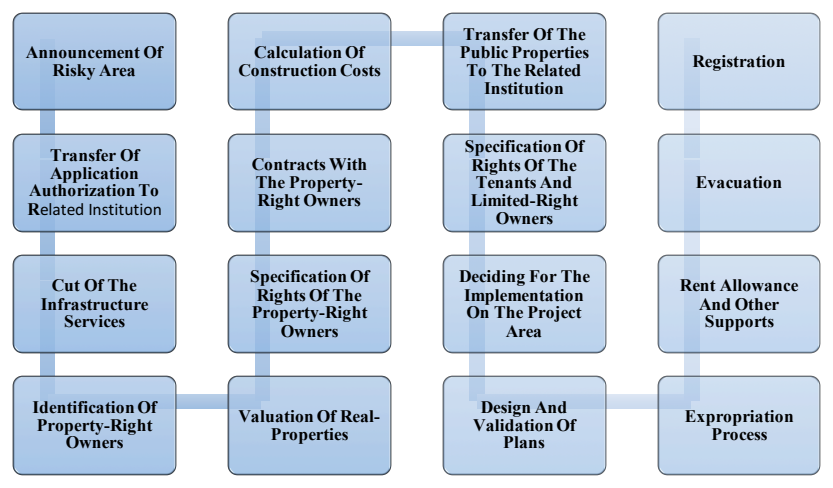

Table 2. Basic steps of a UR project according to the related legislation

\subsubsection{Preliminary Works}

Announcement of Risky Area: In order to define an area as "risky", all necessary documents are prepared according to the law. With the opinions of Disaster and Emergency Management Office "risky area" is identified by the Ministry. The Council of Ministers makes the final decision upon proposal of the Ministry.

Transfer of Application Authorization to the Related Institution: The Ministry has the right to transfer of application authorization to the related institution or to set which of those steps and operations are done by the related institution.

Cut of The Infrastructure Services (Water-Gas-Electricity): During the project, with the proposal of the Ministry or the related institution and the opinion of the property-right owners, the infrastructure services such as water-gas-electricity can be cut off.

\subsubsection{Determination}

Identification of Property-Right Owners: The related institution identifies the property-right owners in the project area and their addresses.

Valuation of Real-Properties: A valuation commission of three experts from the related institution carries out the valuation process of the real-properties or it can be done by the private sector. The process should be done according to the principles of article 11 of the 2942 numbered and 1983 dated Expropriation Law and with respect to the experts' views.

Specification of Rights of the Property-Right Owners: The rights of the property-right owners are specified after collecting documents like land tittles, land tenure allowances, etc.). Related
Institution can do the construction with the project partnership of the property-right owners. Under agreements, construction method can be flat for land method or revenue method.

\subsubsection{Design-Planning}

Contracts with the Property-Right Owners: In order to give housing and shops, primarily constructed in the project area, to the property-right owners, contracts are signed providing that the size and the quality of the housing and shops to be constructed will be decided by the Related Institution.

Calculation of Construction Costs: Firstly, the value of the property (a) in the project area which has calculated according to article 12 of the Legislation is deducted from the construction cost of the new property (b). After such a calculation;

If $a-b>0$ the property right owner can be paid, is given another property from public properties or his development right can be transferred to somewhere else. If $\mathrm{a}-\mathrm{b}<0$ the property right owner must pay the difference to the Related Institution.

Transfer of the Public Properties to the Administration: Treasury lands and other public properties can be transfer to the Ministry on the purpose of the projects under the Law No. 6306 at no cost.

Specification of Rights of the Tenants and Limited-Right Owners: After distribution of the newly built settlements and the offices to the property-right owners on the area, remained settlements and offices can be offered to the tenants and limitedright owners who are the residences of the area for more than one year.

Deciding for The Implementation On the Project Area: According to the Law and related legislation the related institution is authorized to design maps, development plans, implement land readjustment and land consolidation projects, buy the properties, use the pre-emption right, exchanging the properties and transfer the property and development rights elsewhere and transfer the rights to movable goods and also do implementations based on the Public-Private partnership, flat for land and share consideration implementations, construction, determination and distribution of the land share.

Design and Approval of Plans: The Municipalities design the 1:5000 and 1:1000 scaled development plans and the Ministry approves the plans. Development plans are posted publicly for one month from the date of approval by municipalities.

\subsubsection{Implementation-Development}

Expropriation Process: The related institution has the right to buy properties on the area in order to be used for the projects under the Law No. 6306 unless the property-right owners come to an agreement.

Rent Allowance and Other Supports: After agreements are done with the property-right owners, their rents are paid by the related institution from the date of evacuation. The amount and the conditions of the support are announced by the Ministry.

Evacuation: The property-right owners who signed contracts with the Related Institution, have to clear their service bills and all taxes and leave the empty building.

\subsubsection{Registration}

Registration: After constructions are completed, the new flats and offices are delivered to the property-right owners and they are registered at The Land Registration Offices. 


\subsection{Spatial Data Demanding Steps of the UR Process}

The projects covering relatively wide areas with different actors and property types, such as UR projects have to be managed transparently and with the help of geographical information system (GIS). When a database is to be designed there are lots of spatial and non-spatial data have to be collected, managed and processed.

To be able to give the right decision, the right data and information are needed. It is impossible to decide and produce ideas without knowing. The data which are based during an UR project, must be accurate and up-to-date (Yomralığlu, 2013). During an urban regeneration project, implementers have to manage a large-scaled spatial database. This urban spatial database covers all fundamental urban data as well as the planning data. The database may consist of a variety of files. One kind of data is spatial, consisting of location and attribute information. Location can be the latitude and longitude of a reference point, or a set of such points indicating the boundary of a reference area. Another kind of data is non-spatial, consisting only of attribute information, and is not linked with spatial information (Asami, 2008).

When the UR process analyzed some fundamental spatial data and data sources are listed as below and their relation with each step of the UR process is shown with Table 3.

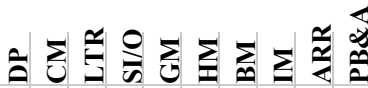

\begin{tabular}{l|l|l|l|l|l|l|l|l|l|l} 
Announcement Of Risky Area & $\mathrm{X}$ & $\mathrm{X}$ & $\mathrm{X}$ & $\mathrm{X}$ & $\mathrm{X}$ & $\mathrm{X}$ & $\mathrm{X}$ & & $\mathrm{X}$
\end{tabular}

\begin{tabular}{|c|c|c|c|c|c|c|c|c|}
\hline $\begin{array}{l}\text { Transfer Of Application } \\
\text { Authorization To Related Institution }\end{array}$ & & & & & & & & \\
\hline Cut Of The Infrastructure Services & & & & & & $\mathrm{X}$ & & \\
\hline $\begin{array}{r}\text { Identification Of Property-Right } \\
\text { Owners }\end{array}$ & & & & & $X$ & & & \\
\hline Valuation Of Real-Properties & $\mathrm{X}$ & & $\mathrm{X}$ & & $\mathrm{X}$ & & & $\mathrm{X}$ \\
\hline $\begin{array}{r}\text { Specification Of Rights Of The } \\
\text { Property-Right Owners }\end{array}$ & & & $X$ & & & & $X$ & \\
\hline $\begin{array}{r}\text { Contracts With The Property-Right } \\
\text { Owners }\end{array}$ & & & & & $X$ & & & \\
\hline Calculation Of Construction Costs & & & & & & & & \\
\hline $\begin{array}{r}\text { Transfer Of The Public Properties } \\
\text { To The Related Institution }\end{array}$ & & & $X$ & & & & & \\
\hline $\begin{array}{l}\text { Specification Of Rights Of The } \\
\text { Tenants And Limited-Right Owners }\end{array}$ & & & $X$ & & & & $X$ & \\
\hline $\begin{array}{r}\text { Deciding For The Implementation } \\
\text { On The Project Area }\end{array}$ & $\mathrm{X}$ & & & & & & & \\
\hline Design And Validation Of Plans & $\mathrm{X}$ & & & & & & & $\mathrm{X}$ \\
\hline Expropriation Process & & $\mathrm{X}$ & $\mathrm{X}$ & & $\mathrm{X}$ & & & \\
\hline Rent Allowance And Other Supports & & & $\mathrm{X}$ & & & & & \\
\hline Evacuation & & & & & & $\mathrm{X}$ & $\mathrm{X}$ & \\
\hline Registration & & & $\mathrm{X}$ & & & & & \\
\hline
\end{tabular}

Table 3. Spatial data demanding steps of UR process

\begin{tabular}{|l|l|}
\hline Development Plan (DP) & Hazard Map (HM) \\
\hline Cadastral Map (CM) & Base Map (BM) \\
\hline Land Title Records & Infrastructure Maps (IM) \\
\hline Satellite Image/ Orthophoto & Address Registration Records \\
\hline Geological Map (GM) & Protected Buildings\&Areas (PB\&A) \\
\hline
\end{tabular}

\subsection{The Urban Regeneration Law in Practice}

In order to comprehend how UR is done by different municipalities two cases are examined. Documents are collected, literature is reviewed and interviews with the experts from the municipalities were done. Two different case studies from two different district municipalities from Istanbul are tried to be explained below. To understand the UR process two municipalities, Gaziosmanpaşa and Kartal, are selected. This selection is based on their background on and experiences with the UR process.

3.3.1 Gaziosmanpaşa Municipality (Istanbul) In Gaziosmanpaşa (GOP), which is one of the most populated districts of Istanbul (Figure 1), urban regeneration activities are executed in 37 percent of the area of the district. 432 hectares in Gaziosmanpaşa district (36.82 \% of all district) have been announced as risky areas (Figure 2) (Usta et al., 2015).

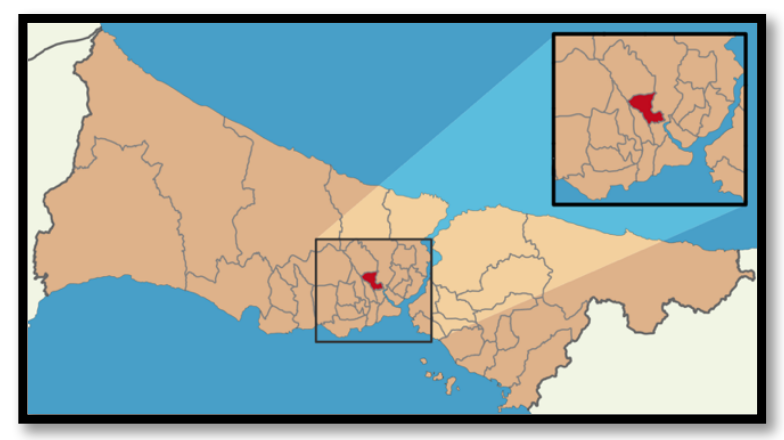

Figure 1. GOP is a district on the European side of Istanbul (URL-1)

After studying documents and interviews basic steps of the UR process of the GOP Municipality is defined as Table 4. From the beginning of urban regeneration process until now, negotiations have been completed with 1684 buildings and agreements have been made with 2809 people; totally 1378 building have been evacuated and demolished (Usta et al., 2015).

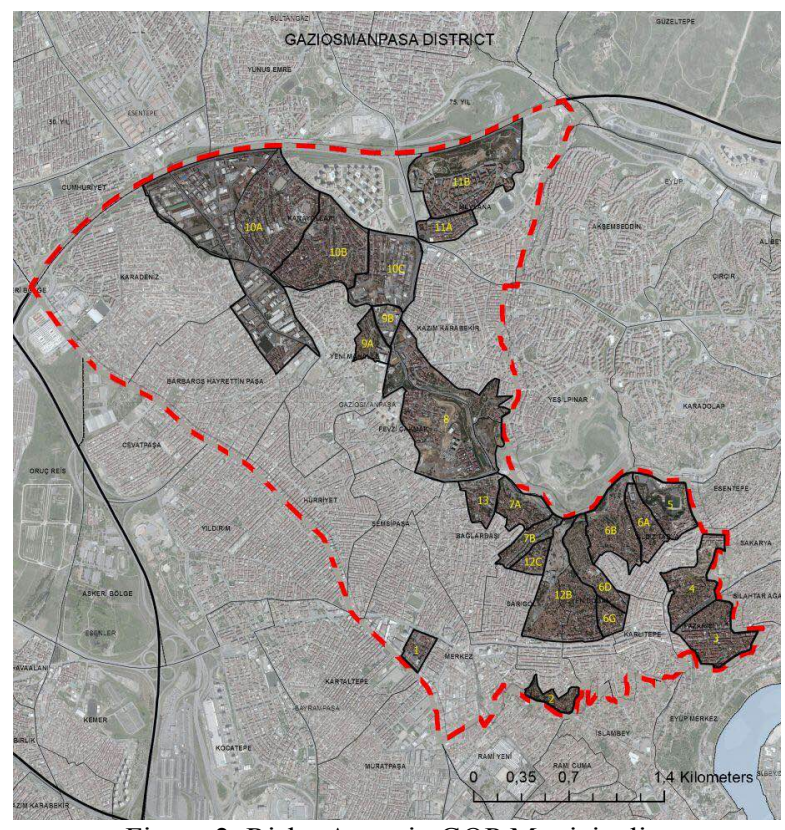

Figure 2. Risky Areas in GOP Municipality 
With the integration of "Strategic Plan" and "Urban Regeneration Master Plan", a concept of "sustainable planning" was adopted. In October 2014, Urban Regeneration Master Plan was completed. In December 2014, implementation guide, development plans with $1 / 5000$ and $1 / 1000$ scale and Urban Design Projects were accomplished (Usta et al., 2015).

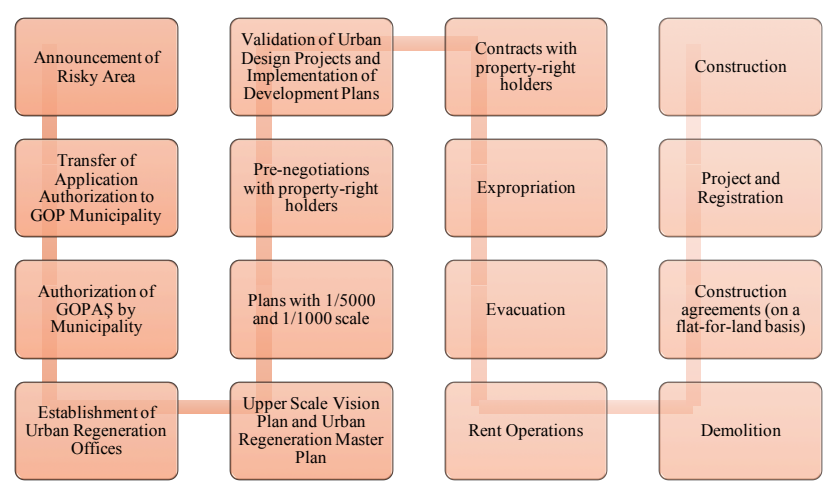

Table 4. Steps of the UR project in GOP (Usta et al., 2015)

The GOP Municipality implements three different distribution methods in different neighborhoods of the district. At some of the project areas the distribution method is flat for flat; after the project everybody can get a new flat only if they can prove their current flat's real-property tax statements and electricity-gaswater invoices.

The other method is area based distribution method. After specifying the property right ownership and the current area of the flat, a contribution cut is calculated and the final distribution ration is determined. The value based distribution method will be used at the lastly announced risky areas. This method has just been started to be implemented. Experts are doing the necessary fieldwork and the results will be monitored later.

3.3.2 Kartal Municipality (Istanbul) Kartal is another district on the Asian side of Istanbul, located on the metropolitan area's eastern shores of the Marmara Sea (Figure 3) (Firidin Özgür, 2013). The primary purpose of the UR projects at Kartal is to redevelop the disused industrial area and illegal settlements next to it and to shift the business and service sector districts those are centered mostly at the European side of Istanbul to Asian side.

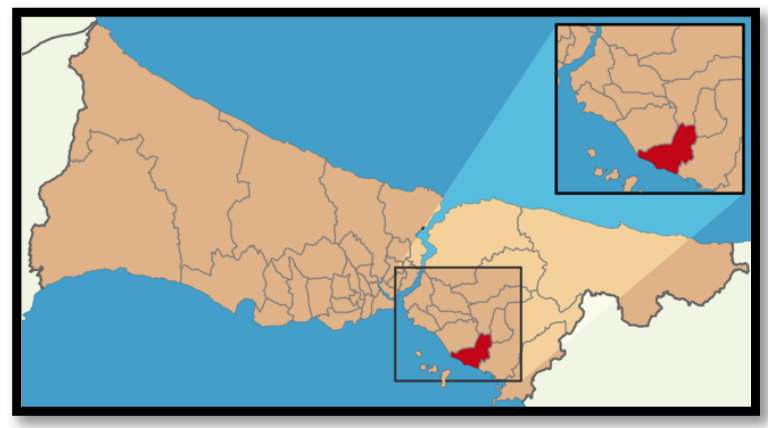

Figure 3. Kartal is a district in Istanbul, on Asian side (URL-2)

In 2006 the mayor of Istanbul decided to hold an international competition to generate development proposals for three strategic sites, one of which was in Kartal. Zaha Hadid won the competition with a highly conceptual urban design scheme (Figure 4). The Istanbul Greater Metropolitan Municipality then began the preparation of the formal 1:5000 Master Plan which will provide a component of legal basis for the implementation of Hadid's redevelopment proposals. The final stage is the preparation of 1:1000 scaled Implementation Plan which is the responsibility of the Kartal Municipality (Kocabas, 2010).

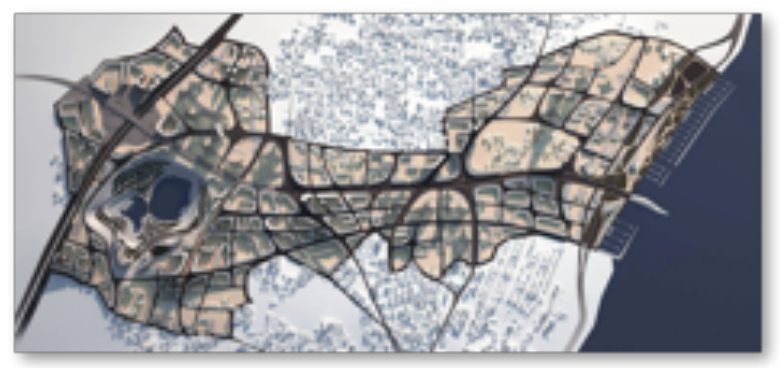

Figure 4. The Kartal Master Plan by Zaha Hadid (URL-3)

Kartal Municipality completed all preparations and made a proposal to the Ministry and on October 2013 the area covering 12,5 hectares is announced as risky area (Figure 5).

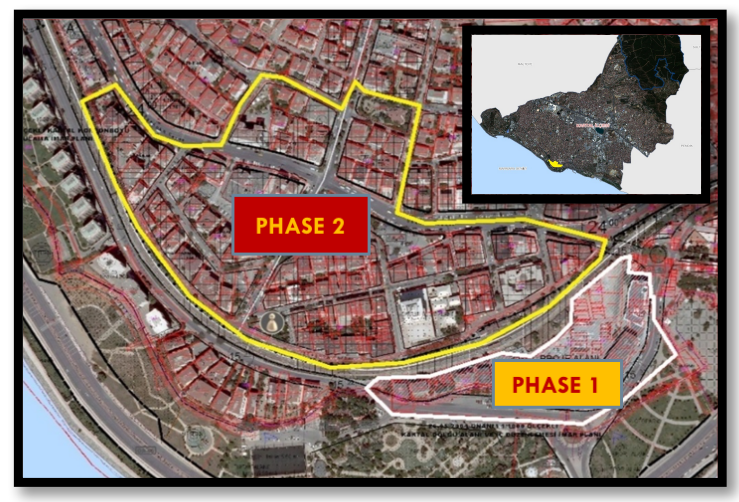

Figure 5. Risky Areas in Kartal Municipality

After the Ministry transferred the application authority to the Kartal Municipality, the Municipality initiated a tender for the fundamental steps the project. The basic steps of the UR process as defined in the tender specification is given with the Table 5 .

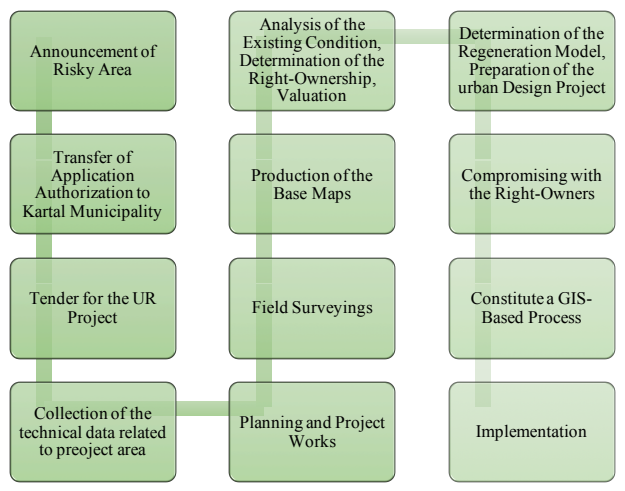

Table 5. Steps of the UR project in Kartal

Kartal Municipality is planning to implement value based distribution method. After preparation of 1:1000 scaled Implementation Plan is completed, experts will prepare the valuation reports and then compromising meetings with the property-right owners will be started. The valuation method and the valuation factors haven't been defined yet. 


\subsection{Comparison}

The UR Law No. 6306 furnishes the related institution with great authorities from the view of political and organizational power used during the project and also data collecting and producing. "Risky Area" decision is a key that opens every door contrary to a regular urban regeneration project which is implemented on a "safe area".

Distribution methods are not specified in the Law and the legislation, so every municipality can use different methods, even at the different neighborhoods of same district. In one project area flat for flat method is being used as a distribution method, whereas in another area a value based method is being used.

When the two cases are examined one of the most important issues is the "ownership right". In this sense specification of the property-right owners must be more clear. In some cases, occupiers of slums, owners of illegal settlements and propertyright owners with land registry are put in the same equation. If these variations are laid barely, the differences on distribution methods can be solved.

About real-property valuation process, the Law refers to the article 11 of 2942 numbered Expropriation Law and indicates that expert opinions, information from other institutions, organizations and local real-property agents have to be regarded. There is no any standards or sufficient legislative regulations on real-property valuation in Turkey except the article 11 of 2942 numbered Expropriation Law. When municipalities need a valuation process, they ask for service from the private sector and this again results with valuation reports far from the standards and valuation factors vary from one to another.

\section{CONCLUSION}

Although the Law No. 6306 is the most extensive legislation up to now, there still are some missing and unclear points. After analysing the selected projects, the following improvements can be suggested.

The risky area definition is not clear; the definition, how it will be defined spatially, who are the experts to sign the technical report for the proposal of a risky area, which questions must be answered in the report, etc. have to be specified on the legislation. The lack of this information is causing the cancellation of some risky areas by the court decision. For instance, in one of the districts of GOP Municipality, a stay of execution was granted by the State of Council. The court decision emphasizes that the technical report of the aforementioned area was prepared without tangible and technical evidences to prove the area is risky from the view of loss of lives and goods $\left(14^{\text {th }}\right.$ Office of Council of State, Decree No: 2014/285).

The distribution methods are unspecified in the Law and the Regulation, so the related institution can decide the method from their own perspective. All methods can be evaluated with all their plus and minuses and the conditions can be determined and stated under which circumstances which method can be implemented.

One of the most difficult steps is to make agreements with the property-right owners. When the related institution tries to make agreements with the people after design of the development plans, the process cannot be operated as a participatory way. It will be easier and more participatory to talk with all of the actors at the project area and give them a chance to express their expectation from the UR process. After receiving the expectations and attaching the most of the ideas to the project, design of the development plans will be more efficient and acceptable. Otherwise the habitants of the area or other initiatives may apply to the court in order to object to the development plans as in one of the project areas in GOP Municipality.

It is important to be able to manage such complex projects with a long list of works and data. The related institutions will save time and labour if they manage the process spatially. They should use the power of GIS. As in the Ankara case, the State of Council cancels the risky area decision because the area is an urban protected area and comment of the Ministry and Tourism had to be added to the proposal since it didn't in this case $\left(14^{\text {th }}\right.$ Office of Council of State, Decree No: 2013/5670). With the usage of the GIS the related institution can easily eliminate such problems. GIS can also be used for real-property valuation. A land value map produced with GIS will be a base map for the UR projects and it provides land values free of speculations and relative effects.

\section{ACKNOWLEDGEMENT}

This research was supported by The Scientific and Technological Research Council of Turkey (TUBITAK) with the 2214-A International Research Fellowship Program for Doctoral Students.

\section{REFERENCES}

Asami, Y., 2008. Urban and Regional Information Infrastructure, Spatial Data Infrastructure for Urban Regeneration, Springer, Japan, pp. 1-13

Balamir, M., 2007. Afet Politikası, Risk ve Planlama (Disaster Policiy, Risk and Planning), paper presented at the disaster symposium, Ankara, 5-7 December

Firidin Özgür, E., 2013. Urban Design Projects and The Planning Process: The Kadikoy Old Market Area Revitalization Project and the Kartal Industrial Area Regeneration Project" J. Cities vol. 31, pp. 208-219

Güzey, Ö., 2016, The last round in restructuring the city: Urban regeneration becomes a state policy of disaster prevention in Turkey. Cities, Volume:50, Elsevier, pp. 40-53

Kocabaş, A., 2010. Kartal Urban Regeneration Project: Challenges, Opportunities and Prospects for the Future, The Sustainable City VI, WIT Press, Great Britain, pp. 571-582

Polat, S., Davutoğlu, S. 2007. Kentsel Dönüşüm Kavramı Üzerine Bursa'da Kükürtlü ve Mudanya Örnekler, Uludağ Üniversitesi Mühendislik ve Mimarlık Fakültesi Dergisi, Volume 12, no. 1, Bursa.

Tarakçı, S., Özkan, H., A., 2015. Evaluation of Law no. 6306 on Transformation of Areas under Disaster Risk from Perspective of Public Spaces - Gezi Park Case, ICONARP International Journal of Architecture and Planning, Vol. 3, Issue 1, pp. 63-82 ISSN: 2147-9380

Thomas, S., 2003. A Glossary of Regeneration and Local Economic Development", Manchester: Local Strategy Center

Roberts, P., 2000. The Evolution, Definition and Purpose of Regeneration", Urban Regeneration A Handbook, London: SAGE Publications 
URL-1 https://tr.wikipedia.org/wiki/Gaziosmanpaşa (01.04.16)

URL-2 https://tr.wikipedia.org/wiki/Kartal,_ìstanbul (01.04.16)

URL-3 http://www.zaha-hadid.com/masterplans/kartal-pendikmasterplan/ (03.04.206)

Usta, H. T., Ülger, N. E., Iban, C., 2015. Urban Regeneration Projects in Istanbul: Gaziosmanpaşa Case, FIG Working Week, Sofia, Bulgaria, 17-21 May 2015

Ülger, N. E., 2010. Türkiye'de Arsa Düzenlemeleri ve Kentsel Dönüşüm, (Land Readjusment and Urban Regeneration in Turkey), Nobel Yayıncılık, Ankara

World Bank, 2008. World Development Report 2009. Reshaping Economic Geography. Washington, DC: World Bank

World Bank, 2015. Rise of the Anatolian Tigers: Turkey Urbanization Review, Main Report. Policy brief;. Washington DC.@WorldBank.

https://openknowledge.worldbank.org/handle/10986/22388

License: CC BY 3.0 IGO

Yomralığlu, T., 2013. Kentsel Dönüşümün Uygulama Boyutu, $1^{\text {st }}$ International Urban Regeneration Symposium, 7-8 October, Ankara 